特集 14

\author{
膵頭十二指腸切除後再建術式における術後合併症と \\ 胆道一消化管同時シンチグラムの検討 \\ 慶應義熟大学外科 ${ }^{1)}$, 栃木県立がんセンター外科 ${ }^{2)}$, 総合太田病院外科 ${ }^{3)}$ \\ 白部多可史 ${ }^{133)}$ 尾形 佳郎2) 高橋 伸 ${ }^{1)}$ \\ 都築 俊治1) 阿部 令彦1)
}

\title{
AN ANALYSIS ON BOTH POSTOPERATIVE COMPLICATION AND HEPATOBILIARY \& GASTROINTESTINAL SCINTIGRAMS USING DOUBLE ISOTOPE TECHNIQUE IN RECONSTRUCTION METHODS OF PANCREATICODUODENECTOMY
}

\author{
Takashi SHIROBE, Yoshiro OGATA, Shin TAKAHASHI, \\ Toshiharu TSUZUKI and Osahiko ABE \\ Dept. of Surgery, School of Medicine, Keio University, \\ Dept. of Surgery, Tochigi Cancer Center \\ and Dept. of Surgery, General Ohta Hospital
}

膵頭十二指腸切除（以下 PD）症例182例について消化管再建術式を合併症と胆道一消化管同時シン チグラムより見た消化吸収機能を中心に検討を加えた。

合併症発生率・手術死亡率に再建術式による差は認められなかった。 また胆道一消化管同時シンチ グラムによる検討では Billroth I 型方式である今永法は Billroth II 型方式である Child 法や Child R-Y 法より食物と胆汁の混合状態が良好であった。しかし術後の体重变動を検討すると両術式間に有 意差はなかった。それに比し，幽門輪保存術式は術後の体重増加が良好で，適応により施行すれば癌 に対する根治性も損なわれない優れた再建術式であると考えられた。

整引用語：膵頭十二指腸切除術，幽門輸保存膵頭十二指腸切除術，胆道一消化管同時シンチグラム

\section{はじめに}

PD 後の消化管再建法は従来 Child 法またはWhipple 法などの Billroth II 型方式（以下 B-II 式）がこれ まで主流を占めてきたが，膵頭部領域癌のより高度な 根治性を求めて拡大手術へと進むにつれ, 消化吸収能 の面より Billroth I 型方式 (以下 B-I 式)である今永法 が見直されてきた。また最近では全胃温存の膵頭十二 指腸切除術（幽門輪保存術式）が，消化吸収機能に優 れた方法として報告されている。一般的には術後合併 症の面からは B-II 式が, 消化吸収機能の面からはB-I

*第33回日消外会総会シンポII・膵頭十二指腸切除術 $<1989$ 年 5 月 8 日受理 $>$ 別刷請求先 : 白部多可史 干373 太田市八幡町29-5 富士重工健保組合総合 太田病院外科
式が有利であると考えられているがその優坌が充分に 比較検討されたとはいえず，施設により再建法が異 なっているのが現状である.

そこで今回各再建術式間の術後合併症と, 食物と胆 汁の混合面よりみた消化吸収能を比較検討するととも に, 幽門輪保存術式の適応及び特徵について検討した ので報告する。

対象およU゙方法

1) 対象

検討対象とした PD 症例は1974年 1 月より 1988年12 月までに慶応大学外科および一部関連施設において手 術された182例である.182例の性別は男性121例，女性 61 例, 年齢は 33 歳から 85 歳の平均63.2歳である, 再建 術式別では Whipple 法 1 例・Child 法22例・Child R.Y 
法55例・今永法67例・幽門輪保存術式37例（B-II 式27 例・B-I 式10例）である. 原疾患別では膵頭部癌85例・ 胆管癌 52 例・Vater 乳頭部癌 27 例・十二指腸癌, 肉腫お よびカルチノイド 7 例・胆豪癌 6 例・胃癌 2 例・慢性 膵炎 2 例・右腎臓癌 1 例の計182例である.

再建術式は年代により変化し，1974年 1月～1976年 4 月ではChild法, 1976年 5 月 1981年 7 月では Child R-Y 法のいわゆる B-II 式再建を行っていたが, 1981年 8 月以降は消化吸収能を考虑し B-I 式である今 永法を採用し，さらに1983年 3 月以降は適応により全 胃温存の幽門輪保存術式を行らようになった。幽門輪 保存術式も当初は B-II 式であったが1986年12月以降 は適応を桩大して B-I 式で行っている（図1）.

2) 方法

（1）術後合併症：対象となった全症例の手術直後上 り退院までに生じた合併症を retrospectiveに各再建 術式別・原疾患別に比較検討した.

（2）消化吸収機能：対象となった症例中 20 例に胆道 一消化管同時シンチグラムを施行し, 胆汁之食物の混 合面より各再建術式間の消化吸収機能を検討した，同 時シンチグラムは以下の方法にしたがって施行した。

(胆道一消化管同時シンチグラム施行法)

消化管シンチグラムとして ${ }^{111}$ In-DTPA を含むプリ

図 1 膵頭十二指腸切除後消化管再建法の推移 1974.1. 1976.4. Child法 1976.5. 1981.7. Child R-Y法
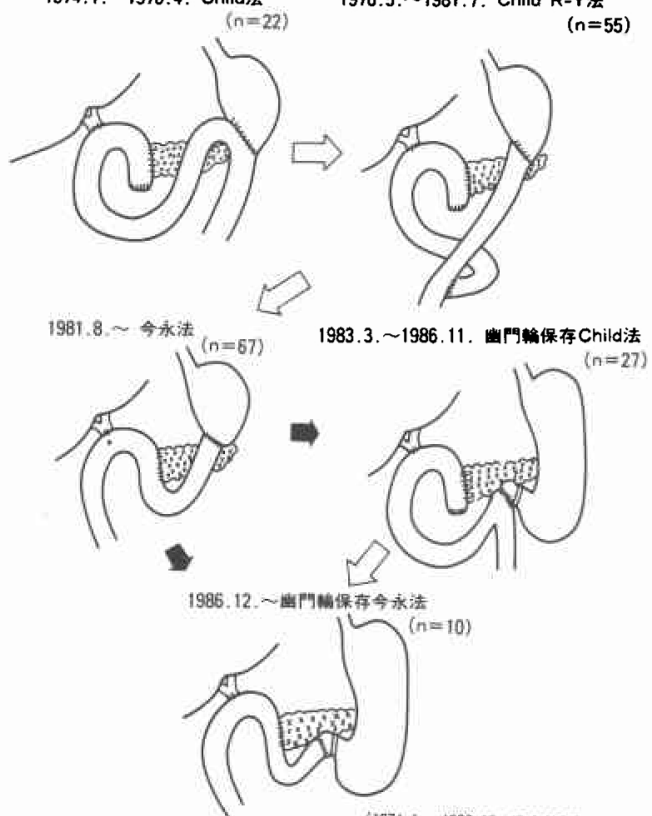

(1974.1, - 1989.12.
ンを㩒取させ, 胆道シンチグラムとして, ${ }^{99 \mathrm{~m}} \mathrm{Tc}$-HIDA を同時に静注する。それぞれを別々にシンチカメラに て撮影しそそのイメージをコンピューターに收録して 重ね合せイメージを行った。

（3）幽門輪保存術式(全胃温存術式)：対象となった 症例中, 下記の適応により37例にこの術式を施行した。 37例を予後・合併症・術後の体重变化について検討乙 た。

\section{（幽門輪保存術式の適応）}

a）良性疾患，b）悪性疾患で 5 番， 6 番のリンパ節 腫脹の無い症例（当初は腈臓癌は適応外としていた）, c）明らかな非治瘜切除症例，d）高齡者扣よび予後不 良症例.

\section{成 繶}

\section{1）術後合併症}

術後合併症を再建術式別にみると発生率では B-II 式19.2\% (15/78), B-I 式19.4\%(13/67), 幽門輪保存 術式16.2\%（6/37）とほとんど変わらず，在院死亡率 はそれぞれ9.0\% (7/78)，7.5\% (5/67)，5.4\%(2/37) で各再建術式間に有意差を認めなかった（表 1).

$\mathrm{PD}$ 後の最も重篤な合併症である膵空腸吻合部縫合 不全を再建術式別にみると，発生率では B-II 式 $5.1 \%$ (4/78)，B.I 式11.9\%(8/67) 幽門輪保存術式8.1\%(3/ 37）で，B-II 式で最も低いものの有意差は認められな かった，一方，原疾患との関係をみると胆管癌 $13.5 \%$ (7/52)，Vater 乳頭部癌 $11.1 \%(3 / 27)$ ，その他 $11.1 \%$ (2/18) であるのに対して, 膵頭部癌では $3.5 \%(3 / 85)$

表 1 膵頭十二指腸切除術後合併症

\begin{tabular}{|c|c|c|c|}
\hline 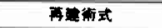 & 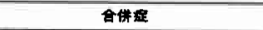 & 発生素 & 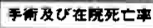 \\
\hline 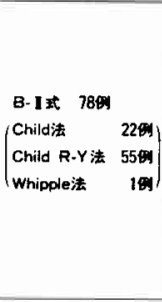 & 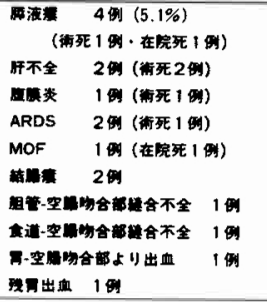 & $\begin{array}{c}15 / 78 \\
(19.2 \%)\end{array}$ & $\begin{array}{c}7 / 78 \\
(9.0 \%)\end{array}$ \\
\hline $\begin{array}{l}\text { B. I 式 679 } \\
\text { (4水法) }\end{array}$ & 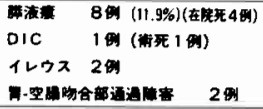 & $\begin{array}{c}13 / 67 \\
(19.4 \%)\end{array}$ & $\begin{array}{c}5 / 67 \\
(7.5 \%)\end{array}$ \\
\hline 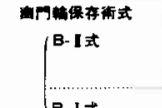 & 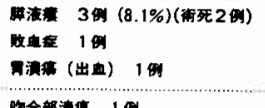 & $\begin{array}{c}6 / 37 \\
(16.2 \%)\end{array}$ & $\begin{array}{c}2 / 37 \\
(5.4 \%)\end{array}$ \\
\hline It & & $\begin{array}{r}34 / 182 \\
(18.7 \%)\end{array}$ & $\begin{array}{l}14 / 182 \\
(7.7 \%)\end{array}$ \\
\hline
\end{tabular}

(1974. 1 1988.12 管大外料) 
と有意に低率であった。

2) 消化吸収機能

表 2 膵頭十二指腸切除後胆道一消化管同時シンチグ ラムの成績

\begin{tabular}{|c|c|c|c|c|c|c|}
\hline 再禹街式 & 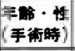 & 疾葸 & $\begin{array}{l}\text { 䚘後年数 } \\
\text { (検查時) }\end{array}$ & 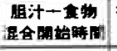 & 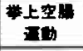 & 湿合状幜 \\
\hline \multirow{4}{*}{$\begin{array}{l}\text { B-I 式 } \\
\text { (Child法 } 1 \text { 付 } \\
\text { Child R-Y法 } \\
\text { 3俰) }\end{array}$} & $45 \cdot M$ & 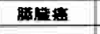 & 6 年 $5 n$ 且 & 50 分 & 好 & 巷好 \\
\hline & $69 \cdot M$ & 勗管量 & 6年 & 80 分 & 中不 & 不息 \\
\hline & $44 \cdot M$ & 䏣管菏 & 4年 1 力周 & 70 分 & 不息 & 不最 \\
\hline & $52 \cdot F$ & 田盘再発 & 7カ月 & 30 分 & 息好 & 好 \\
\hline \multirow{5}{*}{$\begin{array}{c}\text { B- I 式 } \\
\text { (合水法 } 5 \text { (例) }\end{array}$} & $67 \cdot M$ & 䏣箒盘 & 3年8 8 月 & 50 Aी & やゃ不 & 好 \\
\hline & $49 \cdot M$ & 䏣管䒴 & 2 年 8 力 & $30 A$ & 好 & $6 \mathbf{z}^{2}$ \\
\hline & $40 \cdot M$ & 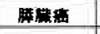 & 1 年 & $10 \hat{A}$ & 好 & 好 \\
\hline & $56 \cdot M$ & 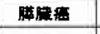 & 6 月月 & 50 分 & 是好 & やゃ不是 \\
\hline & $37 \cdot M$ & 阻管量 & 2力月 & 20 分 & 好 & 好 \\
\hline \multirow{8}{*}{ 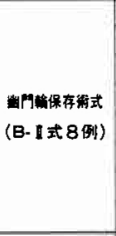 } & $70 \cdot F$ & 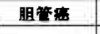 & 3年8力月 & 70 分 & やゃ不良 & やゃ不足 \\
\hline & $47 \cdot F$ & 釈部部重 & 2 年 2 力 & 30 A & 旡好 & 好 \\
\hline & $69 \cdot F$ & 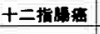 & 2 年 2 用 & 50 分 & 1 好 & やゃ不典 \\
\hline & $47 \cdot M$ & 粗管㶻 & 1 年 & 30 分 & 好 & 好 \\
\hline & $66 \cdot M$ & 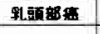 & 7カ月 & 30 分 & やや不 & 好 \\
\hline & $73 \cdot M$ & 䏣管毒 & 3力月 & 30 s & 好 & 是好 \\
\hline & $45 \cdot F$ & 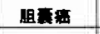 & 3 力月 & 30 分 & 18 & 好 \\
\hline & $72 \cdot M$ & 㤨性䑏众 & 1 力月 & 70 分 & 不食 & やゃ不良 \\
\hline \multirow{3}{*}{ 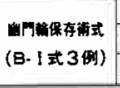 } & $44 \cdot M$ & 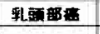 & 3 力月 & 50 分 & やゃ不息 & 量好 \\
\hline & $70 \cdot M$ & 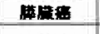 & 2 力月 & 90 分 & やゃ不昷 & 不贵 \\
\hline & $70 \cdot M$ & 组管毒 & 1 力月 & 40 分 & 良好 & 好 \\
\hline
\end{tabular}

(1989.2. 度大外拜)

表 3 幽門輪保存 PD 施行症例の予後（治㦄切除）

\begin{tabular}{|c|c|c|}
\hline 疾急 & 年数・性 & 于 後 \\
\hline \multirow{11}{*}{ 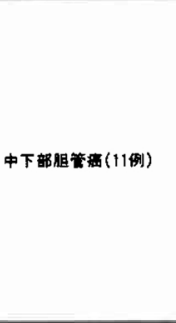 } & $66 \cdot M$ & 5年8カ月生存中 \\
\hline & $70 \cdot F$ & 4年 1 カ月生存中 \\
\hline & $76 \cdot M$ & 3年 6 力月生存中 \\
\hline & $47 \cdot M$ & 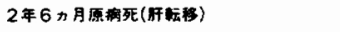 \\
\hline & $60 \cdot M$ & 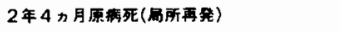 \\
\hline & $68 \cdot M^{*}$ & 2年 2 力月生存中 \\
\hline & $73 \cdot M$ & 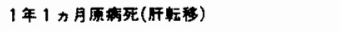 \\
\hline & $59 \cdot M$ & 11カ月原病死(局所再発) \\
\hline & $68 \cdot M^{*}$ & 8カ月生存中 \\
\hline & $73 \cdot M$ & 條死 (29POD) \\
\hline & $64 \cdot M$ & 蔽死 (10POD) \\
\hline \multirow{8}{*}{ 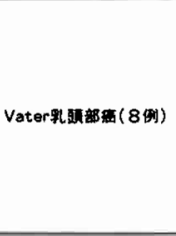 } & $47 \cdot F$ & 5 年11カ月生存中 \\
\hline & $66 \cdot M$ & 3年 1 力月原胴死(肝枟移) \\
\hline & $65 \cdot F$ & 2 年10力月生存中 \\
\hline & $70 \cdot \mathrm{F}$ & 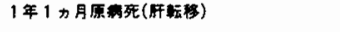 \\
\hline & $56 \cdot M$ & 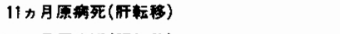 \\
\hline & $63 \cdot F$ & 11カ月原事死(肝枟移) \\
\hline & $44 \cdot M^{*}$ & 4 月生存中 \\
\hline & $45 \cdot F^{*}$ & 4力月生存中 \\
\hline \multirow{5}{*}{ 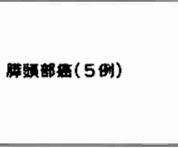 } & $76 \cdot M$ & 5 年 5 力月生存中 \\
\hline & $51 \cdot F^{*}$ & 1 年11カ月生存中 \\
\hline & $68 \cdot F^{*}$ & 7カ月生存中 \\
\hline & $75 \cdot M^{*}$ & 3力月生存中 \\
\hline & $75 \cdot F^{*}$ & 2 力月生存中 \\
\hline \multirow{2}{*}{ 十二指期慧 ( 2 例) } & $69 \cdot F$ & 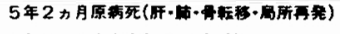 \\
\hline & $76 \cdot M$ & 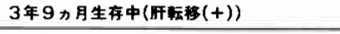 \\
\hline 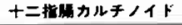 & $56 \cdot M$ & 5 年 1 力月生存中 \\
\hline 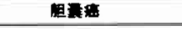 & $45 \cdot F$ & 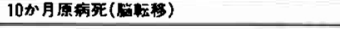 \\
\hline 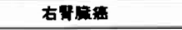 & $67 \cdot M$ & 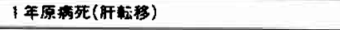 \\
\hline 惯性满焱 & $72 \cdot M$ & 3年11n月生存中 \\
\hline
\end{tabular}

(*):B-1 式 (1989.2. 策大外科)
胆道一消化管同時シンチグラムで各再建術式別に食 物と胆汁の混合開始時間・以後の混合状態・挙上空腸 運動について検討した（表 2）.

今永法では 5 例中 3 例が 30 分以内に混合が開始され 60分以上要した症例は認められなかったのに対して， B-II 式では 4 例中 2 例で混合開始まで 60 分以上必要 としていた. 以後の混合状態怙よび挙上空腸運動も今 永法は B-II 式よりよい傾向があった。一方，幽門輪保 存術式はいずれの項目においても B-I 式と B-II 式の 中間の成績を示した。

\section{3）幽門輪保存術式（全胃温存術式）}

対象となった 37 例中治癒切除例30例について予後と 再発形式について検討した（表 3 )。慢性膵炎を除いた 29例中再発は12例に認められたが，局所再発が明らか であった症例は 3 例であった。 またVater 乳頭部癌で 5 年11か月生存中, 下部胆道癌で 5 年 8 か月生存中, 膵頭部癌で 5 年 5 か月生存中など 5 例の 5 年生存例が みられた。

この術式では術後に胃内容の停滞が認められること があり，その実態を33例について retrospective に検 討した（表 4 ）.16例（48.5\%）の症例で吐き気・食思 不振などの症状が15POD 以降も持続し,最長は44日間 であった。しかし，いずれも一過性で14例 (42.4\%) の症例では全く症状がみられなかった。

1988年12月の時点で 2 年以上生存した症例は 59 例

表 4 幽門輪保存 PD 後の幽門停滞(胃内容停滞)症状 持続時間

\begin{tabular}{|c|c|c|c|}
\hline 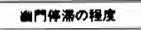 & 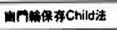 & 由几m保存今水法 & it \\
\hline 金くかかった & $11 / 23(47.8 \%)$ & $3 / 10(30.0 \%)$ & $14 / 33(42.4 \%)$ \\
\hline 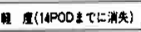 & $2 / 23(8.7 \%)$ & $1 / 10(10.0 \%)$ & $3 / 33(9.1 \%)$ \\
\hline 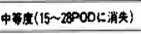 & $8 / 23(34.8 \%)$ & $4 / 10(40.0 \%)$ & $12 / 33(36.4 \%)$ \\
\hline 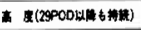 & $2 / 23(8.7 \%)$ & $2 / 10(20.0 \%)$ & $4 / 33(12.1 \%)$ \\
\hline
\end{tabular}

图 $2 \mathrm{PD}$ 術後消化管再建術式別にみた体重変動

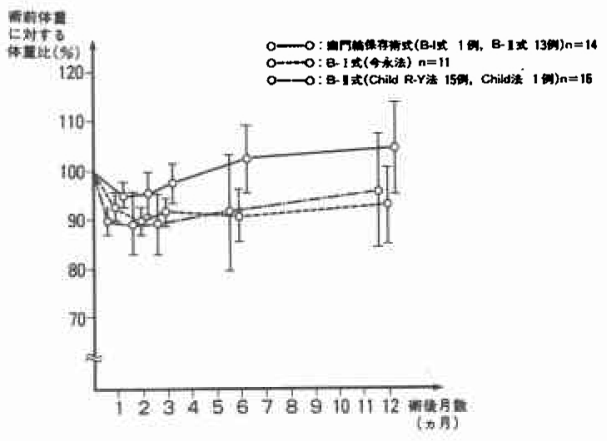


で，このうち41例を対象に術後 1 か月・ 2 か月・ 3 か 月・6か月・12か月の体重の回復状態を検討した（図 2). 幽門輪保存術式は 1 か月と 3 か月で B-II 式に対 して 6 か月ではB-I 式に対してそれぞれ有意に（危険 率 $1 \%$ 以下）体重の回復が良好であった。

\section{考察}

$\mathrm{PD}$ 後の消化管再建術式を合併症と消化吸収機能を 中心に検討したが，以下に項目を設けて考察を加えた。

1）術後合併症

従来 $\mathrm{PD}$ 後の最も致命的な合併症とされてきたのは 膵空腸吻合部縫合不全とそれに起因する腹腔内出血で ある.膵空腸吻合部縫合不全が疑われた症例は全例腹 腔内出血を引き起こした。逆に脺空腸吻合部縫合不全 が明らかでなかった症例でも腹腔内出血症例は胆管空 腸吻合部縫合不全が明らかであった 1 例を除いて膵空 腸吻合部縫合不全症例とした。膵空腸吻合部縫合不全 の発生は再建術式とは関係なく，残存膵機能が低下し ている症例の多い膵頭部癌で有意に低率であった事実 より，残存膵機能と深く関わっていると考えられる。 また膵空腸吻合法も縫合不全発生に大き関与してい ると考えられるが，この点については教室の笛木ら が実験的に各種吻合法を比較検討し, 膵管空腸粘膜吻 合が最も優れた吻合法であることを報告している。今 回対象とした全症例にこの吻合法を採用し縫合不全発 生率は8.2\%(15/185) と比較的良好な成績を得た。胆 管空腸吻合部縫合不全の 1 例を加光た16例の腹腔内出 血症例について険討した(表 5 )。この場合の出血は胃 十二指腸動脈切断端 12 例 - 後膵動脈切断端 2 例 - 胆裏 動脈切断端および門脈各 1 例でいずれも血管切断端よ りの出血と考光られた。発症の時期は14例 $(87.5 \%)$ が術後 2 週間以上であり, この事実は膵液の血管切断

表 5 膵頭十二指腸切除後腹腔内出血症例

\begin{tabular}{|c|c|c|c|c|c|}
\hline No. & 年粭・性 & 晦起晴期 & 出㿼部位 & a & 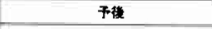 \\
\hline 1 & $\pi \cdot M$ & $22 P O D$ & GDAt]断就 & 閶竡 & 再出血 L死亡(33POD) \\
\hline 2 & $38 \cdot M$ & 22POD & 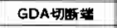 & 開些 & 11年7カ月生存中 \\
\hline 3 & $65 \cdot M$ & $17 P O D$ & GDA场断靖 & 闌盃 & 出血により死C(18POD) \\
\hline 4 & $68 \cdot M$ & $32 P O D$ & GDA切断贱 & 率监 & 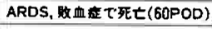 \\
\hline $5^{*}$ & $57 \cdot M$ & 16POD & 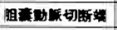 & 間 2 回・エンボリ & 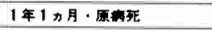 \\
\hline 6 & $56 \cdot M$ & 24POD & GDA㧎糍蛅 & エンボリ & 5年11カ月・原禹研 \\
\hline 7 & $63 \cdot M$ & $17 P O D$ & GDA切镭部 & エンボリ2⿴囗口回 & 研不全 $\rightarrow$ MOFで死亡(72POD) \\
\hline 8 & $64 \cdot M$ & $6 P O D$ & GDA场断模 & 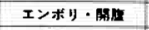 & 再出国，廆C (10POD) \\
\hline 9 & $68 \cdot M$ & 13POD & PDA切断新 & エンボリ & ARDS, 不金で开と(62POD) \\
\hline 10 & $73 \cdot M$ & $29 P O D$ & 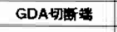 & $(-)$ & 出虫により㱡ट(29POD) \\
\hline 11 & $69 \cdot M$ & $29 P 00$ & GDA切断境 & エンホリリ & 3年1力月生奋中 \\
\hline 12 & $75=\mathbb{E}$ & $27 P O D$ & 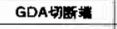 & エンホリ & 2年5力百生在中 \\
\hline 13 & $44 \cdot M$ & 2OPOD & GDA场䉼期 & エンホリ & 1 年 8 カ月生言中 \\
\hline 14 & $67 \cdot F$ & $37 P O D$ & M糔 & Iン゙ホリ2回 & 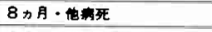 \\
\hline 15 & $74 \cdot M$ & $54 \mathrm{POD}$ & PDAt)断新 & $(-)$ & 出ニにより死亡(5APOD) \\
\hline 16 & $60 \cdot M$ & $35 \mathrm{POD}$ & GDA阴然新 & エン*U & 1年生存中 \\
\hline
\end{tabular}

端腐食開始から出血に至るのに 2 週間以上要する場合 が多いことを示唆している。これらの出血例に対して 初期には再開腹し出血部を直接糸針で止血することを 試みていたが，たとえ一たん止血に成功しても再出血 することが多く 2 回の開腹止血後に embolizationで ようやく完全に止血し救命しえた症例も経験した。 こ れらの経験から少しでも出血が疑われる徵候が見いだ された場合には，直ちに緊急腹部血管造影を施行し出 血部位に対する超選択的 embolization が最も有効で あると考学るに至った。この方法は10例に行い7例は 1 回で止血し，3例で再出血をみたがそのうち 2 例は 再度の embolizationで止血しえた。最終的にも10例中 7 例の救命に成功している。

2）胆道一消化管同時シンチグラム

近年膵頭部領域癌ではより高度な根治性を求めて, 広範な郭清を伴う抎大手術が主流となってきている が，それに伴い消化吸收能の障害が衍後の大きな問題 となってきた。この問題の対応策としてわれわれはよ り生理的な今永法を採用し，さらに全胃を温存する幽 門輪保存術式の採用も積極的に行ってきた。今回検討 した胆道一消化管同時シンチグラムは消化吸収機能の 1 つの指標に過ぎないが，検討した 3 項目いずれも B-I 式が B-II 式上り優れている傾向があった。この事 実は，今永法が消化吸収に優れていることを裏付けて いると考えている。

3）幽門輪保存術式

この術式の原法は1978年 Traverso ら² により報告 されたが，われわれはPD 後の消化吸收障害を軽徽に 留める目的で適応があれば施行してきた，当初は膵臓 癌は対象外としていたが，膵頭部癌で PDを施行した 62 症例の病理検索でリンパ節転移率が 12 番 $16.1 \%, 16$ 番 $21.9 \%$ あるあのに対して，5番，6 番はそれぞれ $1.7 \% ， 6.7 \%$ と低率であったことより，1986年12月以 降は膵蔵癌にも適応を拡大した。この術式を採用した ことが再発の原因となったと考兄られる症例は現在ま で経験しておらず，適応により施行すれば根治性の面 で問題になることはないと考克ている。

この術式を採用するに際し問題となったのは胃内容

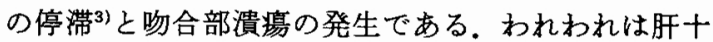
二指腸間膜の郭清は通常どおりに施行しており，迷走 神経幽門枝および右胃動脈は完全に切離している。そ のため諸家の報告以上の胃内容停滞が懸念されたが， 再手術を要するような症例は無く全例一過性であっ た、これは白鳥 ${ }^{48}$ が述べているごとく迷走神経を切離 
しても幽門痉孪は起こらず，原因は明らかではないも のの胃内容の停滞が一時的な胃の運動能低下によるこ とを示唆していると考えられた。 また B-I 式の 1 例で 13POD に吻合部潰湯よりの吐血を経験したが，この症 例も保存的に治瘾し，発症率は $2.7 \%(1 / 37)$ と低率で あった. Itani ら 5) 252例の幽門輸保存術式の集計で 吻合部潰湯の発生は 6 例 $(2.4 \%)$, 再手術例は 2 例 （0.8\%）に過ぎなかったと報告している。一方，残胃 における消化性潰煌の発生に関しては幽門輪を温存す ることにより胆汁の胃内逆流が減り，かえって減少す るといら報告6もある。

今回術後の体重回復状況を従来の B-I 式や B-II 式 と此較検討したが，幽門輪保存術式は従来の術式に比 べ極めて良好であった。それに対して通常型の PDで は B-I 式と B-II 式の間にほとんど差はなく，理論的に はB-I式が優れていると考光られてはいてる，全胃を 温存するか否か程の差はないと思われる。

以上より幽門輪保存術式は適応により施行すれば癌 に対する根治性も損なわれない優れた術式であると考 えられる。

\section{結 語}

1） PD 後の消化管再建法として B-II 式 (Child R-Y 法55例 - Child 法22例 - Whipple 法 1 例) 78例, B.I 式 (今永法) 67例, 幽門輪保存術式 (B-II 式27例, B-I 式 10例)37例の計182例を検討した。各再建術式別の合併
症発生率・在院死亡率に有意の差はなかった。

2）胆道一消化管同時シンチグラムによる食物と胆 汁の混合状態は B-I 式, 幽門輪保存術式・B-II 式の順 に良好であった。

3）幽門輪保存術式は従来の術式に比べて体重回復 が著しいので適応により施行すれぱ優れた術式である と考党られた。

\section{文献}

1）笛木和彦：膵切除後の膵腸吻合術式に関する実験 的並びに臨床的研究. 日外会誌 $86: 725-737$, 1985

2) Traverso LW, Longmire WP Jr: Preservation of the pylorus in pancreaticoduodenectomy. Surg Gynecol Obstet 146 : 959-962, 1978

3) Warshaw AL, Torchiana DL: Delayed gastric emptying after pylorus preserving pancreaticoduodenectomy: Surg Gynecol Obstet $160: 1-4,1985$

4）白鳥常男：迷切で幽門座䘘は括こりません，日外 会誌 $87: 827-833,1986$

5) Kamal MF, Itani $R$, Coleman $E$ et al: Pylorus-preserving Pancreaticoduodenectomy: Ann Surg 204 : 655-664, 1986

6) Brasch JW, Traverso LW, Longmire WP : In preservation of the pylorus: Ann Surg 192 : $309-310,1980$ 